\title{
PENGARUH PEMBERIAN EKSTRAK n-BUTANOL BUAH DEWANDARU (Eugenia uniflora L.) TERHADAP GAMBARAN HISTOPATOLOGI PARU MENCIT (Mus muscullus) JANTAN YANG TERPAPAR ASAP ROKOK
}

\section{THE EFFECT OF GIVING DEWANDARU FRUIT (Eugenia uniflora L.) n-BUTANOL EXTRACT ON THE LUNG HISTOPATHOLOGY PICTURE OF MOUSE (Mus muscullus) WHICH EXPOSED TO CIGARETTE SMOKE}

\author{
PUGUH SANTOSO $^{\bullet}$, ERNA CAHYANINGSIH ${ }^{1}$, GUSTI AYU PUTU EKA DARMAYANTI $^{1}$ \\ ${ }^{1}$ Fakultas Farmasi Universitas Mahaaraswati Denpasar, Jalan Kamboja No. 11A, Denpasar,Bali
}

\begin{abstract}
Abstrak: Dewandaru (Eugenia uniflora L.) merupakan salah satu tanaman obat yang telah banyak digunakan untuk pengobatan tradisional. Rokok merupakan zat adiktif yang dapat mengancam kelangsungan hidup manusia. Racun utama dalam rokok adalah nikotin, tar dan karbon monoksida (CO). Asap rokok adalah penyebab utama kerusakan paru-paru. Salah satu kerusakan nyata adalah stress oksidatif. Dewandaru mengandung senyawa flavonoid yang dapat digunakan sebagai antioksidan. Penelitian ini bertujuan untuk mengetahui ekstrak n-Butanol buah dewandaru pada histopatologi paru mencit jantan yang dipapar asap rokok. Penelitian ini merupakan penelitian eksperimental dengan randomized posttest only with control group design, yang menggunakan sampel 30 ekor mencit jantan yang dibagi menjadi tiga kelompok. Kelompok I sebagai kelompok kontrol diberikan paparan asap rokok dan larutan CMC dosis 0,5 ml/hari. Kelompok II dan III sebagai kelompok perlakuan diberikan paparan asap rokok 30 menit/hari selama 20 hari dan diberikan ekstrak n-Butanol buah dewandaru dengan dosis $100 \mathrm{mg} / \mathrm{KbBB}$ dan dosis $200 \mathrm{mg} / \mathrm{KgBB}$ pada hari ketiga sampai hari ke-10. Pada hari ke-21 mencit dikorbankan dan dibedah untuk diambil parunya, pembuatan preparat histopatologi, dan pemeriksaan histopatologi paru mencit. Data hasil penelitian dianalisis secara deskriptif kualitatif. Dari hasil penelitian dapat disimpulkan bahwa gambaran histopatologi paru mencit jantan yang diberikan ekstrak n-Butanol buah dewandaru dapat menunjukkan adanya perbaikan jaringan sel pada kelompok yang diberikan ekstrak. Dan dosis yang paling menunjukkan adanya perbaikan yaitu dosis 200 $\mathrm{mg} / \mathrm{KgBB}$.
\end{abstract}

Kata kunci: rokok, stress oksidatif, ekstrak buah dewandaru, mencit jantan.

Abstract: Dewandaru (Eugenia uniflora L.) is one of the medicinal plants that have been widely used for traditional medicine. Cigarettes are addictive substances that can threaten human survival. The main toxins in cigarettes are nicotine, tar and carbon monoxide (CO). Cigarette smoke is a major cause of lung damages. One of the damages is oxidative stress. Dewandaru contains flavonoid compounds that can be used as antioxidants. This study aims to determine the n-Butanol extract of dewandaru fruit on the lung histopathology of male mice exposed to cigarette smoke. This was an experimental study with randomized post-test only with control group design, which used 30 male mice divided into three groups. Group I as a control group was given exposure to cigarette smoke and a CMC solution of $0.5 \mathrm{ml} /$ day. Group II and III as the treatment group were given 30 minutes / day of cigarette smoke exposure for 20 days and given n-Butanol extract of dewandaru fruit at a dose of $100 \mathrm{mg} / \mathrm{KgBW}$ and a dose of $200 \mathrm{mg} / \mathrm{KgBW}$ on the third day until the 10th day. On Day 21 the mice were sacrificed and dissected for their lungs, making histopathological preparations, and lung histopathology examinations. The results of the research data were analyzed qualitatively. It was found that the lung histopathological features of male mice which were given n-Butanol extract of dewandaru fruit showed an improvement in cell tissue. The dose which showed the most improvement was $200 \mathrm{mg} / \mathrm{KgBW}$. Keywords: cigarettes, dewandaru fruit extract, male mice, oxidative stress.

•correspondence email: p.santoso@unmas.ac.id 


\section{PENDAHULUAN}

Rokok merupakan zat adiktif yang dapat mengancam kelangsungan hidup manusia di negara maju dan berkembang. Indonesia sebagai negara berkembang, konsumsi rokok meningkat secara pesat dari tahun ke tahun dan saat ini Indonesia merupakan negara nomor 3 (tiga) dengan jumlah perokok tertinggi di dunia setelah Cina dan India. Berdasarkan data WHO konsumsi rokok dapat membunuh satu orang setiap 10 detik, hingga saat ini diperkirakan jumlah perokok dunia mencapai 1,35 milyar orang (Menkes RI, 2013).

Racun utama dalam rokok adalah nikotin, tar dan karbon monoksida (CO). Nikotin memiliki efek adiktif dan psikoaktif. Tar merupakan zat karsinogenik yang dapat menyebabkan kanker pada saluran nafas dan paru-paru. Karbon monoksida dihasilkan dari sisa pembakaran yang tidak sempurna. Sebanyak $85 \%$ asap rokok yang berasal dari ujung rokok yang terbakar dapat dihirup bebas oleh orang disekitarnya (side stream cigarette smoke) (Indra SN, 2011).

Dewandaru (Eugenia uniflora) merupakan salah satu tanaman obat yang telah banyak digunakan oleh masyarakat Indonesia untuk pengobatan tradisional selain itu dewandaru juga telah diteliti secara ilmiah (Santoso, 2018). Hasil uji fitokimia buah dewandaru menunjukkan adanya alkaloid, glikosida, tannin, saponin, dan terpenoid (Onwudiwe, 2013). Berbagai Warna buah Dewandaru sesuai warnanya orange banyak mengandung beta karoten, warna merah banyak mngandung lycopen, warna ungu banyak mendaung antosianin ungu buah Dewandaru (Bageti, 2011).Senyawa antosianin.tanin pada buah Dewandaru mengurangi perosidasi lipid dan meningkatkan SOD (Pathise, et al.,2017) mempunyai aktivitas antioksidan yang tinggi karena kandungan kimia aktif antosianin Dewandaru banyak mengandung senyawa flavonoid, dimana 96,7\% aktivitas antioksidan ekstrak daun dewandaru disumbangkan oleh senyawa flavonoid. Flavonoid dapat digunakan sebagai pelindung mukosa lambung, antioksidan, dan mengobati gangguan fungsi hati (Sutari, 2008).
Penelitian ilmiah terkait dengan buah dewandaru di Indonesia masih sangat jarang dilakukan. Berdasarkan uraian di atas peneliti tertarik untuk menguji efek buah dewandaru, yaitu mekanisme flavonoid dalam perbaikan gambaran histopatologi paru mencit jantan yang disebabkan oleh peningkatan produksi radikal bebas akibat paparan asap rokok.

\section{METODE PENELITIAN}

Rancangan Penelitian. Jenis penelitian yang digunakan adalah penelitian eksperimental dengan menggunakan metode randomizide post-test with control group design.

Bahan. Bahan yang digunakan dalam penelitian ini adalah buah dewandaru yang berwarna merah marun, rokok filter, CMC 0,5\%, larutan buffer formalin $10 \%$.

Alat. Alat-alat yang di gunakan adalah timbangan analitik Digital Scale (Olaus, USA), oven (Memmert), sonde oral, corong Buchner, blender (philip), rotary evaporator (Buchii), alat-alat gelas (glassware), box paparan, gunting bedah, dan mikroskop.

Hewan Coba. Hewan coba yang digunakan adalah mencit jantan dengan kriteria inklusi yaitu mencit jantan yang berumur 2-3 bulan dengan berat badan 20-40 gram dan dengan kriteria drop out yaitu hewan coba yang mati pada saat penelitian. Hewan coba diperoleh di Jl. Pulau Moyo No. 15 Perum Telkom No. 10A.

Perlakuan Pada Hewan Coba. Mencit diadaptasi dengan lingkungan tempat penelitian selama 2 hari, sebanyak 27 ekor dikelompokkan menjadi 3 kelompok, masing-masing kelompok terdiri dari 9 ekor mencit. Kelompok terdiri dari kelompok kontrol dan kelompok perlakuan yang diberikan ekstrak n-butanol buah dewandaru dosis 100 $\mathrm{mg} / \mathrm{KgBB}$ dan dosis $200 \mathrm{mg} / \mathrm{KgBB}$. Kelompok kontrol dan kelompok perlakuan diberikan paparan asap rokok dimulai pada hari ketiga, masing- 
masing kelompok diberikan paparan asap rokok selama 30 menit setiap harinya dan pemaparan dilakukan selama 8 hari, kemudian diberikan ekstrak n-butanol buah dewandaru untuk kelompok perlakuan dosis $100 \mathrm{mg} / \mathrm{KgBB}$ sebanyak $0,5 \mathrm{ml}$ dan dosis $200 \mathrm{mg} / \mathrm{KgBB}$ sebanyak $1 \mathrm{ml}$ dengan cara disonde, pemberian ekstrak dilakukan selama 8 hari setelah hewan coba dipapar asap rokok.

Pengujian Histopatologi Paru. Pada hari ke-11 mencit dikorbankan untuk diambil parunya untuk dibuat preparat histopatologi, setelah pengambilan jaringan paru selesai hewan coba dimusnahkan dengan cara dibakar. Pada pembuatan preparat dilakukan dengan proses pemotongan paru dengan ketebalan $5 \mathrm{~mm}$ yang diletakkan di tissue cassette. Hasil pemotongan dimasukkan ke dalam mesin tissue processor otomatis dan dilakukan proses dehidrasi bertingkat selama 2 jam. Selanjutnya dilakukan penanaman dalam blok dengan paraffin cair. Terakhir dilakukan pemotongan blok dan pewarnaan dengan Hematoxili-Eosin. Pemeriksaan histopatologi dilakukan dengan pemeriksaan pada tiga lapang pandang di bawah mikroskop dengan pembesaran 400x. Perubahan yang diamati yaitu terjadinya kerusakan nekrosis jaringan pada bronkiolus.

\section{HASIL DAN PEMBAHASAN}

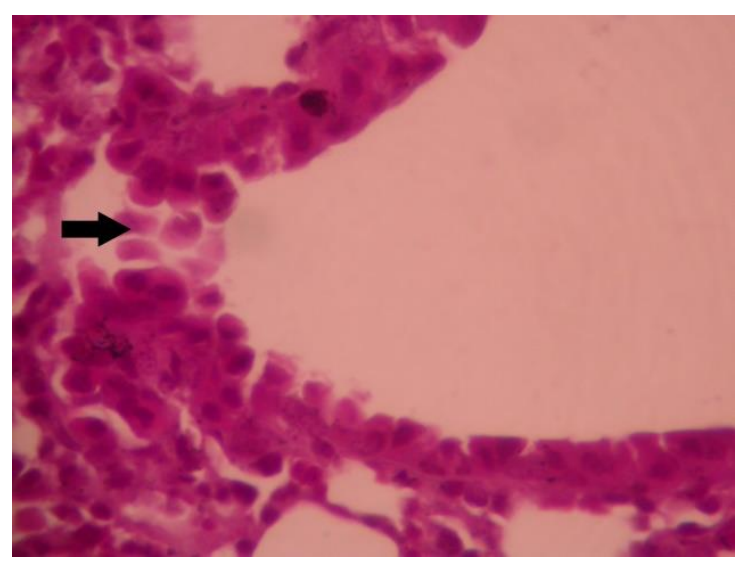

Gambar 1. Kelompok kontrol

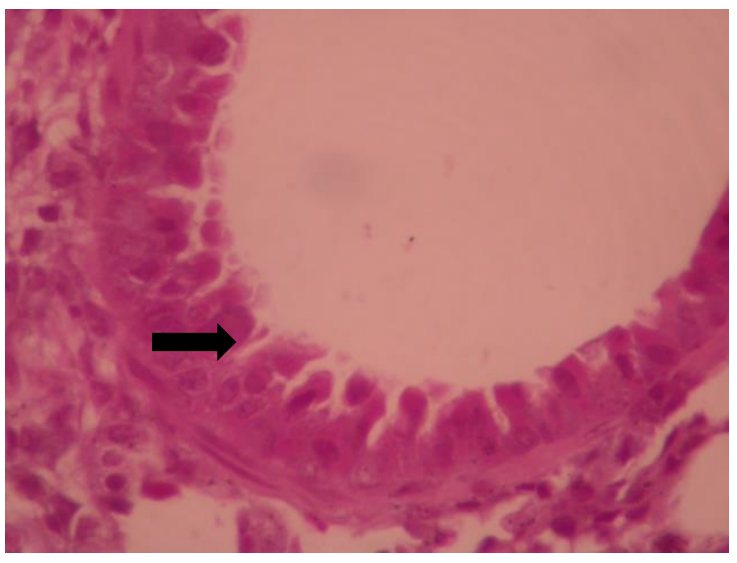

Gambar 2. Ekstrak n-Butanol buah dewandaru dosis $100 \mathrm{mg} / \mathrm{KgBB}$

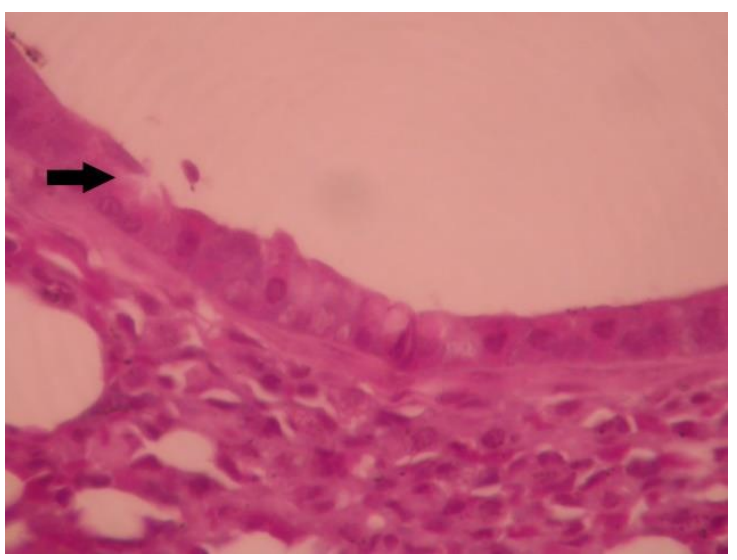

Gambar 3. Ekstrak n-Butanol buah dewandaru dosis $200 \mathrm{mg} / \mathrm{KgBB}$

Dalam penelitian ini dilakukan pemeriksaan histopatologi paru mencit setelah dipapar asap rokok dan diberikan ekstrak n-Butanol buah dewandaru. Sebelum diberikan perlakuan mencit diadaptasi selama dua hari dan mencit dipuasakan selama 18 jam dan air minum tetap diberikan agar mencit tidak mengalami dehidrasi. Mencit jantan sebanyak 30 ekor dikelompokkan secara acak menjadi tiga kelompok, sehingga setiap kelompok terdiri dari 10 ekor mencit. Setiap kelompok diberikan paparan asap rokok selama 30 menit setiap hari yang dimulai dihari ketiga dan pemaparan dilakukan selama 20 hari. Kelompok kontrol hanya diberikan larutan CMC, sedangkan kelompok perlakuan I dan II diberikan ekstrak nButanol buah dewandaru dosis $100 \mathrm{mg} / \mathrm{KgBB}$ dan $200 \mathrm{mg} / \mathrm{KgBB}$ pemberian ekstrak dilakukan secara oral.

Pada hari ke-21 mencit dikorbankan dan dibedah untuk pengambilan paru dan dilakukan 
pembuatan preparat histopatologi dengan pewarnaan HE (Hematoxilin-Eosin), selanjutnya dilakukan pengamatan pada tiga lapang pandang di bawah mikroskop dengan pembesaran 400x. Pada kelompok kontrol menunjukkan hasil bahwa paparan asap rokok dalam 8 hari telah merusak jaringan paru mencit yang ditunjukkan dengan adanya nekrosis jaringan paru pada sel bronkiolus. Nekrosis yang ditemukan pada paru mencit kelompok kontrol adalah jenis karioreksis. Karioreksis merupakan keadaan dimana pecahnya inti menjadi bebarapa bagian. Pada tahap karioreksis, inti akan hancur menjadi fragmenfragmen zat kromatin di dalam sel dan akhirnya kromatin menjadi lisis yang disebut dengan kariolisis (Kumar, 2007). Pada gambaran histopatologi kelompok yang diberikan ekstrak nButanol buah dewandaru dosis $100 \mathrm{mg} / \mathrm{KgBB}$ dan dosis $200 \mathrm{mg} / \mathrm{KgBB}$ masih ditemukan adanya nekrosis, namun sudah terlihat adanya perbedaan pada kelompok perlakuan, dimana gambaran histopatologi pada kelompok perlakuan mulai menunjukkan adanya perbaikan sel bronkiolus pada jaringan paru mencit dibandingkan pada kelompok kontrol yang mengalami nekrosis cukup parah. Nekrosis jaringan terjadi akibat aktivitas asap rokok dalam paru-paru.yang menyebabkan terjadinya stress oksidatif. Stress oksidatif memegang peranan penting terhadap terjadinya kerusakan histopatologi paru dan penyakit paru kronis (PPOK). Stress oksidatif akan memicu peningkatan ROS, adanya peningkatan ROS dalam sel menyebabkan metabolisme sel terganggu, salah satunya adalah transport membran. Sehingga dibutuhkan senyawa yang mampu menetralkan radikal bebas yang disebabkan oleh asap rokok.

Antioksidan bertugas dalam menetralkan radikal bebas dengan menyumbangkan sebuah atom hidrogen dari gugus hidroksil fenolik yang akan mengubah radikal bebas menjadi senyawa yang stabil dan mencegah timbulnya respon inflamasi terus menerus. Kerja antioksidan sebagai penangkal radikal bebas melalui upaya pentransferan atom hidrogen ke senyawa radikal bebas sehingga menjadi stabil dan menghambat stress oksidatif (Nassar, et al., 2007).

Dari hasil pengamatan efek ekstrak nButanol buah dewandaru untuk melindungi paru- paru mencit sudah dapat terlihat adanya perbaikan pada kerusakan paru mencit yang mengalami nekrosis. Namun pemberian ekstrak n-Butanol buah dewandaru dosis $100 \mathrm{mg} / \mathrm{KgBB}$ dan 200 $\mathrm{mg} / \mathrm{KgBB}$ tersebut belum sempurna dalam memperbaiki sel yang mengalami nekrosis. Hal ini kemungkinan terjadi karena waktu pengamatan yang pendek belum mampu sepenuhnya menghilangkan nekrosis pada histopatologi paru mencit yang diakibatkan oleh paparan asap rokok yang diberikan selama perlakuan. Dengan demikian ekstrak n-Butanol buah dewandaru masih berpotensi untuk dibuktikan khasiatnya secara ilmiah dalam penelitian lebih lanjut.

\section{SIMPULAN}

Berdasarkan penelitian yang telah dilakukan dapat disimpulkan bahwa ekstrak n-Butanol buah dewandaru (Eugenia uniflora L.) memiliki pengaruh terhadap gambaran histopatologi paru mencit (Mus muscullus) jantan yang terpapar asap rokok. Dosis $200 \mathrm{mg} / \mathrm{KgBB}$ merupakan dosis yang paling efektif dalam memberikan perbaikan sel bronkiolus namun parbaikan yang diberikan belum sempurna, hal ini kemungkinan terjadi karena waktu perlakuan yang singkat.

\section{DAFTAR PUSTAKA}

Bagetti, M., E.M.P Faco., J. Picolo., GE Hirsch. 2011.Physicochemical characterization and antioxidant capacity of pitanga fruits (Eugenia uniflora L.)" FoodScience and Technology, vol.31, p. $34-38$

Indra SN. 2011. Hubungan Antara Tingkat Stres dengan Perilaku Merokok pada Siswa Lakilaki Perokok SMKN 2 Batusangkar. Universitas Andalas.

Kumar, V., Cotran, RS., Robbins, SL. 2007. Buku Ajar Patologi 7th ed, Vol. 2. Jakarta : EGC. 
Marks DB, Allan DM, Colleen MS. 1996. Biokimia Kedokteran Dasar. Terjemahan dr. Brahm UP SpKK. Jakarta: EGC.

Onwudiwe, N. N. \&. J. P., 2010. Phytochemical and Acute Toxicity/Lethality Study of Ethanol Exctrac Eugenia uniflora L Pulp. Research Journal Phamacognosy and Phitochemistry, 2(4), 356-339.

Pathise, O. S., Victor C.C., Natalia, P.B., Mayara,S.P.,Juliane,S.C.2017. Eugenia uniflora (red type) standardized extrac: a potent pharmacological metabolic syndrome damage management. Biomedicine \& Pharmacoterherapy, 92(5), pp. 935-941

Santoso,2018. Manfaat Dewandaru dalam Kesehatan

Sutari, Ilik. 2008. Efek Hepatoprotektif Ekstrak Etanol 70\% Daun Dewandaru (Eugenia Uniflora L.) Terhadap Mencit Jantan Galur Swiss Terinduksi Parasetamol. (Skripsi, Universitas Muhammadiyah Surakarta). 